\title{
CELLS NAMED AFTER PERSONS
}

\author{
A. Ivanova, N. Dimitrov, N. Pirovski* \\ Faculty of Medicine, Tarkia University, Stara Zagora, Bulgaria
}

\begin{abstract}
The Relationship between the cells and their names is part of the history of medicine. Purpose: Systematization of objects in histology and cytology named with the names of their discoverers or other persons, and introduction of the society with short historical reference. Tasks: 1 . Making a table with the cells named after their researchers. 2. A Brief reference to the explorers. 3. Analysis of the reasons for the use of their name, including occupation and nationality. 3. Presentation of the results in the medical faculty and the Medical college. Material and methods: Book review of the available educational literature, as well as of contemporary publications online. Results: In the table we listed 54 cells with names of persons. Ten of them are associated with pathological conditions. They are named after personalities of different professions and nationalities, but mainly of anatomy and physiology researchers and physicians. The prevailing researchers are from Western Europe and Russia. Cells with different morphology are named after the same person. Conclusions: The names of some persons deserve to be written in the history of medicine. This does not override the need for a uniform anatomical nomenclature and a coherent classification of cells.
\end{abstract}

Key words: Cell, Name, history

\section{INTRODUCTION}

The relationship between the cells and their names, the history of their discovery, and how the discoveries of the cells have helped science are facinating, motivationg and always interesting to look at.

Objective: Systematization of the objects in histology and cytology named with the names of their discoverers and familiarization of the society with the historical reference.

Tasks: 1. Create a table of cells named after their researchers. 2. Brief summary of the discoverers. 3. Analysis of the reasons for the use of their name, including profession and nationality. 3. Presentation of the results at the medical faculty and the medical college of the trainees.

\section{MATERIAL AND METHODS}

A literary review of the available for the medical students in Bulgarian literature and modern online publications.

\footnotetext{
*Correspondence to: Nikola L. Pirovski, Department of Anatomy, Faculty of Medicine, Trakia University, 11 Armejska Str., BG-6000 Stara Zagora, Bulgaria; e-mail: pirovsky@abv.bg
}

\section{RESULTS}

In a table, we listed 54 objects named with names of scientists. Ten of them are associated with pathological conditions. They are named after an individuals with different professions and nationalities, but mainly for researchers, anatomists, physiologists and doctors. Researchers from Western Europe and Russia predominate. Cells of different morphology are called after the same person. Table 1 List of cells named after persons- example., Figure 1 Profession of the persons, Figure 2 Year of naming, Table 2 Common difficulties with cell names.

The main question is whether the cells named after their researchers should bear their names or should be named by an anatomical nomenclature related to their location and the function they perform? The work of scientists who have devoted their lives to contribut to the development of science is still important to be reflected in textbooks on history of medicine, while student material needs to be clear, concise and logical. For this reason, the available information should be retained, but distributed in the correct category to make it easier to be found and used. 
Table 1. List of cells named after persons- example

\begin{tabular}{|c|c|c|c|c|c|c|c|}
\hline \multicolumn{8}{|c|}{ Tabl. 1 List of cells named after persons- example } \\
\hline & Cell name & alternative name & description & person & profession & year & nationality \\
\hline 1 & Anichkov cell & harth mast cell & $\begin{array}{c}\text { It is located in the connective tissue of the } \\
\text { myocardium and exhibits histocytic activity, } \\
\text { characterized by the arrangement of chromatin as a } \\
\text { gear wheel }\end{array}$ & $\begin{array}{l}\text { Nikolay Nikolaevich } \\
\text { Anichkov }\end{array}$ & pathomorphology & 1885 & Russia \\
\hline 2 & $\begin{array}{l}\text { Армани- } \\
\text { Ебщайн }\end{array}$ & Human herpesviru,EBV & $\begin{array}{l}\text { light glycoen containing cell found in diabetes mellitus } \\
\text { in the proximal canal of the kidney }\end{array}$ & Луциано Армани & & 1872 & \\
\hline 13 & Shwan cells & Glial cells & myelin producing cells for myelin neuron sheaths & Theodor Schwann & Biology & 1810 & now in Germany \\
\hline
\end{tabular}

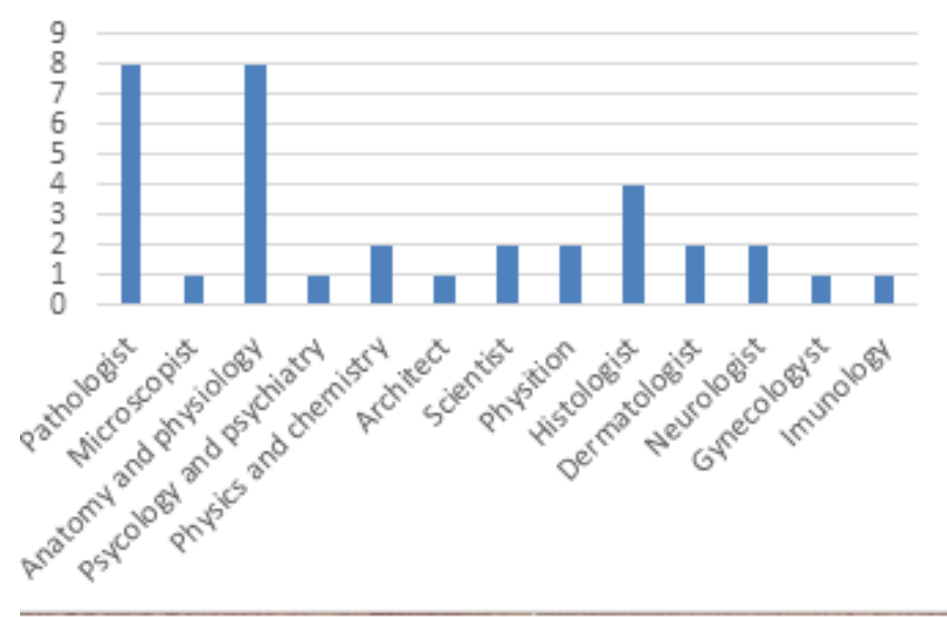

Figure 1. Profession of the persons

* The biography of some of the persons was difficult to find; some had more than one profession but were listed only under one category,

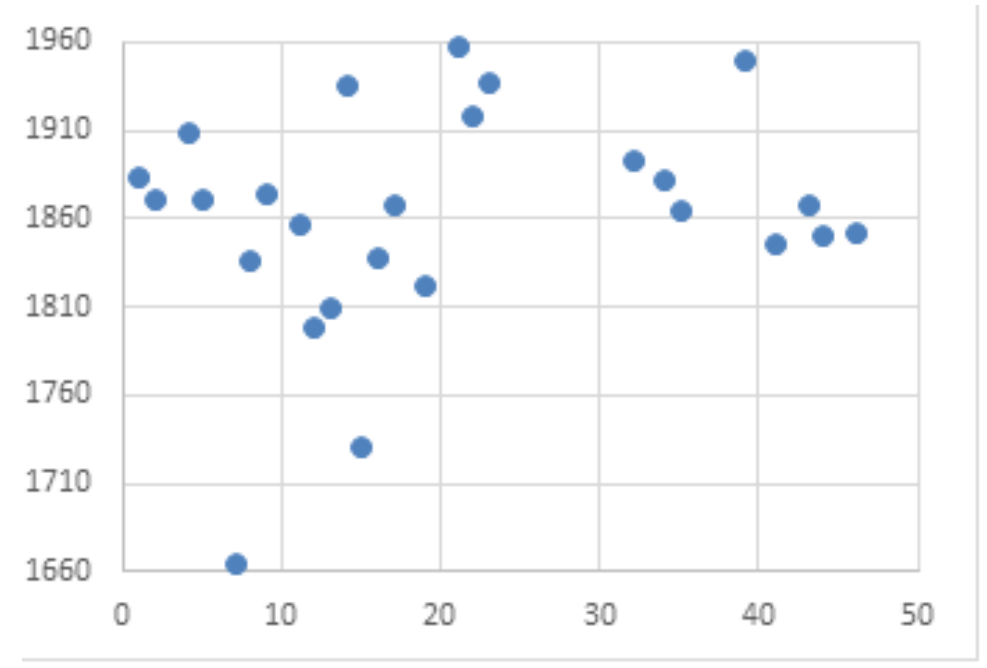

Figure 2. Year of naming

Table 2. Common difficulties with cell names

\begin{tabular}{|r|l|r|}
\hline & Tabl. 2 Common difficulties with cell names \\
\hline 1 & Cells with double names & 7 \\
\hline 2 & Different cells named on the same person & 2 \\
\hline 3 & Cells named after more than one person & 9 \\
\hline
\end{tabular}




\section{DISCUSSION}

Excessive workload of the histology and anatomy textbooks with names of individuals is unnecessary and has less benefit. It is impossible in such textbooks to present and provide sufficient detail on the contribution and performance of these scientists. The name of the researcher does not give any information about the morphology and function of the structure under consideration. Sometimes, in different countries, the same structures are named differently, and different structures have the same person's name. Such confusions are inadmissible for scientific literature. It also raises the question of the ethics of the conducted research, and not all experiments in the past have been acceptable from a contemporary ethical point of view. The time distance between researchers and the modern student also makes it difficult to understand the work done. History and individuals have a context that is difficult to understand because of the temporal and cultural differences. For example, when looking at a city in which a scientist lived and worked, it is also necessary to quote the year, since at different times this city may have been in different countries. The use of the international anatomical nomenclature, most recently revised in 2012, removes these doubts and provides a lean, logical scheme for studying the human body and students and researchers should adhere to it. Historians and researchers of the history of medicine are entirely in their right to affirm
PIROVSKI N., et al.

different personalities and biographies of contributors to medicine, and the importance of studying this subject must be emphasized. The use of person names to designate cells in daily medical practice can only be justified with the need for the newly discovered structures that have not yet been classified by the international anatomical community.

\section{CONCLUSIONS}

The names of some persons deserve to be written in the history of medicine. This does not override the need for a uniform anatomical nomenclature and a coherent classification of cells.

\section{REFERENCES}

1. Ulumbekov, E., Large encyclopedic dictionary of medical terms: more than 100 thousand terms, GEOTAR-Media, Aug. 8

2. Chuchkov, H., Sivrev, D. Human embryology with clinical correlations. Thracian University, Stara Zagora. ISBN: 978954-338-067-1, (2013)

3. Chuchkov, H., Sivrev, D. Histological techniques. Universal Press, Thracian

University, Stara Zagora, (2007).

4. Ovcharov, V., Vankov, V., Human Anatomy, Sofia, Arso, 2016

6. Lenchenko, E., Cytology, Histology and Embryology, ISBN 978-5-9532-0635-8, KolosS, 2009

7. Gartner, L., Histology For Medical Students, Elsevier Science, ISBN 9781483163499, 2014 